\section{The Sturucture of a New Carotenoid \\ Tethyanine in Sea Sponge Tethya amamensis*1}

Short Paper

The six carotenoid hydrocarbons isolated from Tethya amamensis were already reported in our previous work, ${ }^{1,2)}$ and furthermore two minor pigments isorenieracistene and renieracistene have been structurally elucidated. ${ }^{\text {s) }}$

The present study reports on the isolation of a new aromatic carotenoid, which is shown to be 3,4-didehydro- $\beta, \phi$-carotene (I).

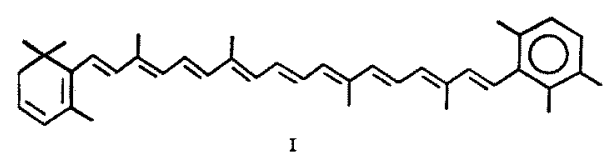

The crude carotenoid was extracted with acetone and separated on an alumina column (G-III) using $1 \%$ acetone in petroleum ether (PE.) as a developing solvent. The second fraction was rechromatographed on a $\mathrm{MgO}$ column developed with $3 \%$ acetone in $\mathrm{PE}$. and then purified through a sucrose column developed with PE. The objective pigment was crystallized from PE.

The characteristics of this pigment run as follows: m.p.: $130-132^{\circ} \mathrm{C}, \lambda_{\max }$ (PE.): $456 \mathrm{~nm}, \mathrm{MS}: \mathrm{M}^{+}(530)$, M-2 (528), M-92 (438), M-106 (424), M-133 (397), MM-158 (372), M-175 (355), M-188 (342), M-198 (332), M-201(329), 133 (base peak), ' ${ }^{1}$ H-NMR: $\delta 1.04$ (s, 6H), $1.88(\mathrm{~s}, 3 \mathrm{H}), 1.98(\mathrm{~s}, 9 \mathrm{H}), 2.08(\mathrm{~s}, 3 \mathrm{H}), 2.23(\mathrm{~s}, 3 \mathrm{H})$, $2.26(\mathrm{~s}, 6 \mathrm{H}), 5.76-6.96(\mathrm{~m}, 18 \mathrm{H})$, IR (KBr): 3025, 2970, $2920,2860,2820,1460,1444,1365,1358,1005,968$, $830,809,730 \mathrm{~cm}^{-1}$.

Although the IR spectrum and mass spectrum of this pigment were much similar to those of tethyatene, the visible absorption spectrum had the shorter wavelength of one maximal absorption compared with that of tethyatene as shown in Fig. 1. The signals o: methyl protons in ${ }^{1} \mathrm{H}-\mathrm{NMR}$ spectrum at $\delta 1.04$ and 1.88 indicated that the one end group of this pigment is 3,4didehydro- $\beta$-carotene, while $\delta 2.23$ and 2.26 denoted that the other end group is $\phi$-carotene. ${ }^{4}$ From these

(Accepted November 26, 1983)

*1 海綿䖝物 Tethya amamensis 中の新カ口テノイド Tethyanine $\sigma$ 構造.

" 田中淑人・山本 任; 鹿児島大学水産学部 - 鹿少 舟市下萦田 4-50-20.

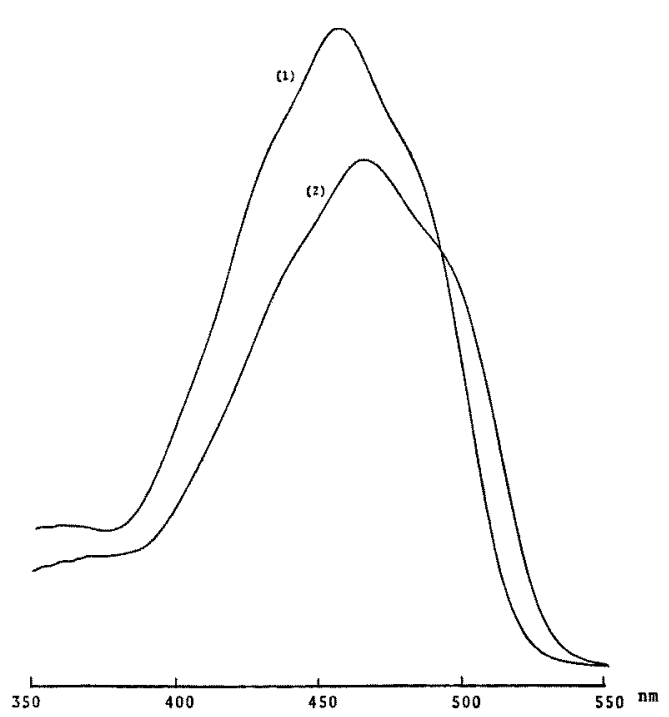

Fig. 1. Visible absorption spectra of tethyanine (1) and tethyatene (2).

results, therefore, we proposed tethyanine, 3,4-didehydro- $\beta, \phi$-carotne as a new aromatic carotenoid from Tethya amamensis and named tethyanine as a meaning of a structural isomer of tethyatene.

This pigment was contained at a rate of ca. $2 \%$ of total carotenoid in Tethya amanensis.

We wish to thank Professor M. YAMAGUCHI (Department of Chemistry, Kyushu University) for the NMR measurement.

Yoshito TANAKA*2 and Atsushi Yamamoto*2 Laboratory of Marine Biochemistry, Faculty of Fisheries, Kagoshima University, 4-50-20, Shimoarata, Kagoshima 890, Japan.

\section{References}

1) Y. TANAKA and T. KATAYAMA: Bull. Japan. Soc. Sci. Fish., 43, 1229-1232 (1977).

2) Y. TanaKa, T. Soljima, and T. Katayama: Bull. Japan. Soc. Sci. Fish., 44, 1283-1285 (1978).

3) Y. Tanaka, A. Yamamoto, and T. Katayama: Bull. Japan. Soc. Sci. Fish., 48, 1651-1655 (1982).

4) G. P. Moss and B. C. L. WeEDon: in "Chemistry and Biochemistry of Plant Pigments" (ed. by T. W. Goodwin), Academic Press, New York, 1976, p. 149. 